\title{
OPPIVAA ORGANISAATIOTA ETSIMÄSSÄ
}

\author{
Ajatuksia Peter Sengen teoksesta The Fifth Discipline
}

\author{
Oppivan organisaation ensisijainen olomuoto on visio. Elinikäisen oppimisen \\ muotona se on perustaltaan keskeneräinen ja sen rakenteeseen \\ sisältyy riskejä ja epäonnistumisia. Siksi oppiva organisaatio on myös \\ ainutkertainen. Sitä ei voida kopioida tai monistaa. Oppiva organisaatio \\ ei avaudu organisaatiokaavioiden avulla, vaan sen polttopisteenä ovat \\ yksilöiden keskinäisen kanssakäymisen pelisäännöt.
}

Artikkelini perustuu Peter Sengen (Senge 1990 ja Senge ym. 1994) näkemykseen oppivasta organisaatiosta. Senge rakentaa näkemyksensä tieteellisen ja arkitiedon rajoja rikkoen, erilaisia kulttuurikäytäntöjä peilaten sekä konkretisoi ajatuksensa arkielämän moninaisilla esimerkeillä. Sengeläinen oppiva organisaatio on aineksiltaan kokonaisuus, jossa sosiaalipsykologia, kvanttifysiikka, liiketaloustiede, antropologia, sosiologia, lingvistiikka, arabialainen kansantarinaperinne ja japanilainen tapakulttuuri kohtaavat ja jossa asevarustelun laajentumiselle, Shellin liiketoimintastrategialle, Australian verohallinnolle tai vaikkapa lasten tavoille leikkiä hiekkalaatikolla on löydettävissä yhteinen kosketuspinta.

Käsitteellisesti ( ${ }^{1}$ ks. viitteet artikkelin lopussa) oppiva organisaatio rakentuu viiteen kulmakiveen: henkilökohtaiseen hallintaan, mentaalisiin malleihin, yhteiseen visioon, tiimioppimiseen ja järjestelmäajatteluun. Näiden sisällöllisesti monin tavoin sidoksissa olevien käsitekokonaisuuksien lisäksi Senge rakentaa ajatteluaan systeemisten arkkityyppien ${ }^{2}$ avulla, jotka kuvaavat tavanomaisia arkielämän ajattelun ja päätöstilanteiden rakenteita. Systeemiset arkkityypit Senge avaa tapausesimerkein.

Alustavasti oppimista voidaan luonnehtia erottamalla ajattelun ja toiminnan reaktiivinen ja generatiivinen taso ${ }^{3}$. Reaktiivisella tasolla oppiminen on aika- ja tilasuhteiden osalta rajoittunutta, tilannesidonnaista ja tapahtumakeskeistä. Generoivassa ${ }^{4}$ eli luovassa ja tuottavassa oppimisessa oppimishorisontti laajenee aika- ja tilasuhteiden osalta, mutta sen polttopisteenä on myös itse oppimisen ja sosiaalistumisen prosessit eli tavat, joilla tuotamme mentaalisia mallejamme. Generoivan oppimisen perusedellytyksenä on vakiintuneiden mentaalisten malliemme kyseenalaistaminen.

Oppivan organisaation ensisijainen olomuoto on visio, se on sen oppimisen muotona perustaltaan keskeneräinen ja sen rakentamiseen sisältyy riskejä ja epäonnistumisia. ${ }^{5}$ Tästä syystä oppiva organisaatio on myös ainutkertainen, sitä ei voida kopioida eikä monistaa. Oppiva organisaatio ei avaudu organisaatiokaavioiden avulla, vaan sen polttopisteenä ovat yksilöiden keskinäisen kanssakäymisen pelisäännöt. Kyse on yksilöiden, ryhmien ja yhteisöjen sosialisaatiomallien arvioinnista ja oppimiskäytäntöjen uudelleen-normittamisesta, joista Senge avaa keskustelun. ${ }^{6}$

Rajaan tarkasteluni kahteen kysymykseen: Mitkä ovat oppivan organisaation perusolettamukset ja lähtökohdat? Mitä oppiminen on oppivassa organisaatiossa? Vastatessani niihin, typistän Sengen moniaineksista ja vahvasti kontekstisidonnaista tarkastelua.

\section{Todellisuus ja tulkinta}

Ajattelutapamme ja todellisuuden kuvaustapamme ovat erottamaton osa sitä kokonaisuutta, jota kutsumme todellisuudeksi (Senge 1990, 238-239 ja 1994, 2-3). Fyysikko Werner Heisenbergerin vuonna 1927 esittämän epävarmuuden periaatteen mukaan mitatessamme erilaisia todellisuuden ilmiöitä muutamme samalla todellisuutta. Viimekätistä tai lopullista totuutta ei voida koskaan saavuttaa. Oppiva organisaatio rakentuu samaan käsitykseen todellisuudesta, kuin se väittää todellisuuden muutoinkin olevan: Valmista mallia, muottia tai reseptiä oppivalle organisaatiolle ei ole, mutta suuntaviittoja, rakennuspuita ja risteäviä oppimispolkuja kylläkin.

Senge (1990, 283-284) painottaa vaihtoehtojen etsimisen ja esittämisen merkitystä erottamalla konvergentin ja divergentin todellisuuden. Konvergentissa todellisuudessa vastausvaihtoehdot erilaisiin kysymyksiin ja ongelmiin lähenevät toisiaan, vastausvaihtoehdot ovat laadullisesti yhteismitallisia ja vastausvaihtoehtojen mahdollinen kenttä suppenee, kun kysymykseen tai ongelmaan etsitään ratkaisua. Esimerkkinä konvergentista todellisuudesta voidaan esittää kysymys: "Mikä on nopein reitti henkilöautolla Jyväskylästä Helsinkiin?" Divergentissä todellisuudessa kysymyksiin on olemassa useita laadullisesti yhteismitattomia vastauksia, kuten 
esimerkiksi kysymykseen "Miksi haluat matkustaa Helsinkiin?" Useimmat arkitodellisuutta koskevat kysymykset ja ongelmat ovat Sengen mukaan divergenttejä.

Oppiva organisaatio on lähtökohdaltaan hermeneuttinen: Kyseessä on "syvällinen tietoisuuden muutos, jossa oivallamme kuinka todellisuus jatkuvasti vaikuttaa meihin ja me vaikutamme todellisuuteen" (Senge 1990, 78). Todellisuus näyttäytyy Sengelle vastavuoroisten prosessien kehinä, joissa syytä ja seurausta on mahdoton yksiselitteisesti erottaa. Näkökulmalla on relevanssia erityisesti ekologisissa kysymyksissä, joihin perehtyneet asiantuntijat pitävät ensisijaisena sitä, että ihmisen olisi kyettävä näkemään itsensä osana luontoa ja ekologista järjestelmää.

\section{Oppimisrajoitteiden tunnistaminen}

Oppimisrajoitteita voidaan löytää koko länsimaisesta kulttuurista, työorganisaatioista, tieteellisestä tutkimuksesta, virallisista suunnittelu- ja ennustamismenetelmistä, varhaiskasvatuksesta sekä henkilökohtaisista ajattelumalleista.

Länsimaiset kielet ovat lineaarisuuteen ja kausaalisuuteen rakentuvina sekä toimijakeskeisinä yksinkertaistavia ja harhaisia. Lineaarisuus ja toimijakeskeisyys ilmenee länsimaisten kielten perusrakenteessa (subjekti, verbi, objekti) ja käsitteiden merkityssisältöjen yksiselitteisyydessä. Kielen lineaarista ja toimijakeskeistä ilmaisua noudattaen voin esimerkiksi sanoa: "Täytän lasin vedellä". Todellisuudessa operoin kuitenkin vedensäätelyjärjestelmällä, joka koostuu halutusta veden pinnan tasosta, lasissa vallitsevasta veden pinnan tasosta, kahden edellä mainitun välisestä erotuksesta, vesihanan asennosta ja veden virtauksesta. Ilmaus "täytän lasin vedellä" on esimerkki kielestä, jossa toiminnan keskipisteeksi itsensä asettava inhimillinen toimija operoi ulkoisella ja elottomalla todellisuudella. (Senge 1990, 69-78; Goodman, Kemeny \& Roberts 1994, 113-120).

Vedensäätelyjärjestelmä on esimerkki myös järjestelmäajattelun ${ }^{7}$ mukaisesta palautteen määrittelystä. Lause "Täytän lasin vedellä" voidaan jakaa kahdeksi lauseeksi: "Hanaa koskettava käteni kontrolloi veden virtausta lasiin" ja "Veden pinnan taso lasissa kontrolloi vesihanalla olevaa kättäni". Nämäkään kielen ilmaisut eivät Sengen mukaan ole vielä riittäviä, koska ne kuvaavat -etenkin kun on kyse monimutkaisista inhimillistä toiminnoista - vain osittain vastavuoroisia prosesseja. Yleisesti palaute merkitsee järjestelmäajattelussa vaikutusten vastavuoroista virtausta, jossa jokainen vaikutus on sekä syy että seuraus. jokaisessa järjestelmässä inhimillinen toimija on osa palauteprosessia.

Lineaarinen ajattelu ja järjestelmäajattelu eroavat ratkaisevasti oppimiskulttuurin osalta. Lineaarisessa ajattelussa on aina joku selkeä alue, johon vastuu voidaan sijoittaa. Kun asiat eivät suju suunnitellulla tavalla, syyllistetään joko joku muu tai itsemme (Senge 1990, 78). Järjestelmäajattelun omaksuminen ongelmallistaa eettisen vastuukysymyksen, ei ole olemassa vastapuolta tai kausaaliselle ajattelulle ominaista yksiselitteisiä toimijaa, jonka seurauksena syyllinen voitaisiin nimetä. järjestelmäajattelun omaksuminen merkitsee rajan huokoistumista väärän ja oikean tai hyvän ja pahan välillä sekä irtautumismahdollisuutta syyllisyyskulttuurista.

Toinen oppimista rajoittava tekijä on todellisuuden sirpaleinen ja staattinen hahmottamistapamme, erillisinä yksittäistapahtumina, poikkileikkauksina ja yksittäisiin päivittäistilanteisiin juuttuen. Tätä oppimisrajoitetta vahvistavat myös useat perinteiset tieteenalat, jotka pyrkivät rajaamaan ja eristämään todellisuuden asiantuntemusreviirinsä mukaisesti. Esimerkiksi taloustiede ja psykologia, jakavat todellisuuden siisteiksi alaosastoiksi, joissa toimivat asiantuntijat ratkovat ongelmia puhtaina "taloudellisina" tai "henkilöstöongelmina". Sama todellisuuden hahmottamistapa ilmenee myös sekä yksityisellä että julkisella sektorilla laajasti käytettävissä analysoinnin, suunnittelun ja ennustamisen työkaluissa, jotka soveltuvat erillisistä yksityiskohdista muodostuvan monimutkaisuuden ${ }^{8}$ käsittelyyn. (Senge 1990, 21, 52, 63-65 ja 283; Senge 1994, 45-46)

Sengen (1994, 12) teesinä on, että kaikki olennaiset yhteiskuntien ja organisaatioiden henkiinjäämisen peruskysymykset, kuten esimerkiksi asevarustelu, ympäristötuhot, talouden kilpailu, paikallisyhteisöjen hajoaminen tai julkisen koulutusjärjestelmän rapautuminen, ilmenevät hitaina ja asteittaisina prosesseina. jotta ajattelutapamme vastaisivat paremmin todellisuuden monimutkaisuutta, pitäisi todellisuutta hahmottaa riittävän pitkäjänteisesti sekä asioiden keskinäisyhteyksiä ja muutossuhteita tarkastellen.

Myös vallitsevaa länsimaista työkulttuuria voidaan tarkastella oppimisrajoitteiden peilinä. Ajankäyttöä koskeva normisto on rakentunut nopeuden lisäämisen periaatteeseen. ${ }^{9}$ Senge toteaakin, että hitaiden ja asteittaisten prosessien tunnistaminen edellyttää rajua hiljentämistä nykyisestä "raivoisasta vauhdista". Edelleen ihmisiä opetetaan olemaan liian lojaaleja työtä kohtaan tavalla, joka ehkäisee kokonaisuuksien ymmärtämistä. Funktionaalinen työnjako ja raskaat hierarkiat vahvistavat tätä reviiriperusteista ("toimin tehtävässäni") työhön sitoutumistapaa ja johtavat kokemuksesta oppimisen harhakuvitelmaan. ${ }^{10}$ 
Länsimaisia työorganisaatioita leimaa "puskemiskulttuuri", jonka ytimenä on periaate: "Kovalla työllä kaikki esteet ovat ylitettävissä". Yksilöt ja organisaatiot ylistävät sekä puskemista - "enemmän samaa, tarvitsemme isomman vasaran" - että sen mukanaan tuomia kärsimyksiä, mutta samalla sokeudumme sille kuinka itse olemme vaikuttaneet ongelmien ja esteiden syntyyn. Tyypillistä tämänkaltaiselle kulttuurille on myös kyvyttömyys asettaa vaihtoehtoja ("joko-tai" -ajattelu) ja taipumus etsiä syyllisiä. Työorganisaatioiden oppimisrasitteena on myös autoritaarinen ajattelu, jossa "kuka" on aina tärkeämpi kuin "mitä". Ne turvautuvat helppoihin ja ilmiselviin ratkaisuihin, jotka usein kuitenkin jäävät oireisiin vaikuttamisen tasolle. Seuraava taakan siirtämisen arkkityyppi on esimerkki oiretason ratkaisusta henkilöstöongelmissa:

Taakan siirtäminen henkilöstöongelmissa (Senge 1990, 108)

Tasapainottavat prosessit

Vahvistava prosessi

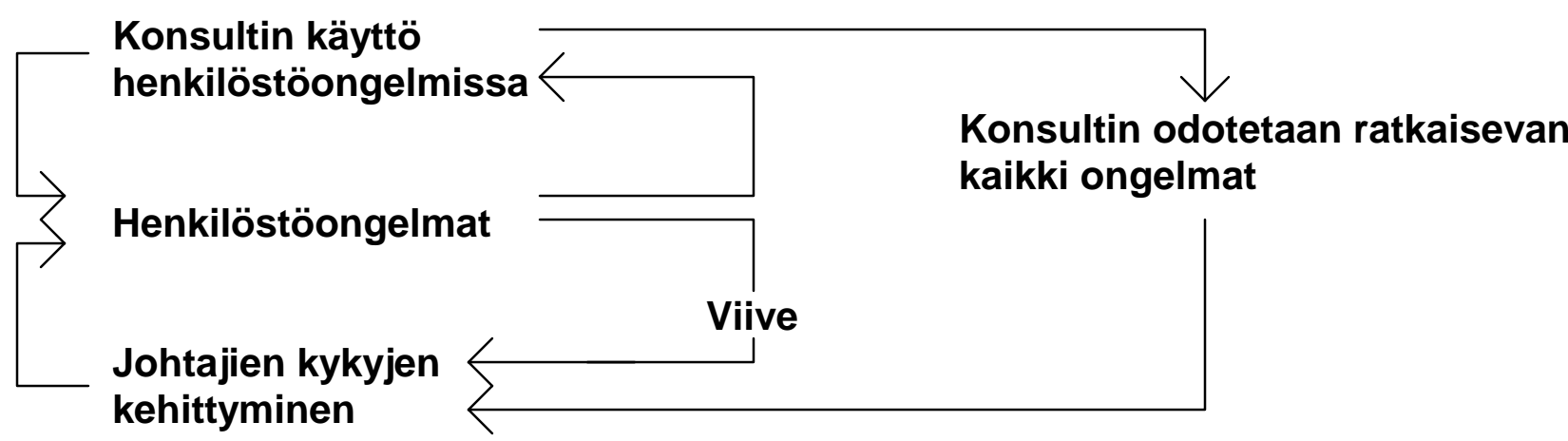

Monet johtajat ovat taipuvaisia käyttämään konsultteja ratkaistakseen henkilöstöongelmia. Konsultti voi ratkaista ongelman ja varsinkin jos konsultin käyttö johtaa hyvään lopputulokseen, konsulttiin turvaudutaan yhä uudestaan ja uudestaan. Ennen pitkää konsulttia käytetään jokaiseen ongelmaan, mutta johtajien kyky ratkaista vastaavia ongelmia estyy, johtamiskustannukset kasvavat ja alaisten kunnioitus johtajia kohtaan heikkenee.

Taakan siirtämisen arkkityyppi on käyttäytymisrakenteen kuvaus, jossa hyvää tarkoittavat oiretason ratkaisut (vahvistava prosessi) tosiasiallisesti huonontavat asioiden tilaa pidemmällä aikavälillä. Käyttämällä oiretason ratkaisua, vapaudutaan paineista, joita syntyy joko ulkoisesti tai sisäisesti monissa tilanteissa, joissa "pitäisi tehdä jotakin". Ilman että kukaan olisi välttämättä tehnyt tietoista päätöstä, taakka siirretään oiretasolle, koska luottamus käytettyihin ratkaisuihin lisääntyy. Taakan siirtämisen arkkityyppi ilmentää mentaalisiin malleihin sisältyviä oppimisrajoitteita siinä yksinkertaisessa muodossa, että viiveellä tapahtuva hidas muutos (esimerkin tasapainottavat prosessit) jää piiloiseksi. (Senge 1990, 104-113; Goodman \& Karash 1994, 161-163)

\section{Henkilökohtainen hallinta}

Henkilökohtainen hallinta (Senge 1990, 147-161) perustuu totuuteen sitoutumiseen ja kykyyn ylläpitää luovia jännitteitä. Sitoutumisessa totuuteen omaa ajattelumaailmaa kyseenalaistetaan, pyritään laajentamaan tietoisuutta ja syventämään ymmärrystä tapahtumien taustalla olevista rakenteista. Erityisesti kyky nähdä oman käyttäytymisen taustalla olevia rakenteellisia konflikteja on ominainen korkean henkilökohtaisen hallinnan omaaville ihmisille. Esimerkkinä Senge käyttää oman selviytymistrategiansa, tahdonvoimastrategian, tunnistamista tilanteissa, joissa hän on kokenut jääneensä pulaan suurten projektien kriittisissä vaiheissa. Kesti vuosikausia ennen kuin Senge tunnisti oman tahdonvoimastrategiansa erityisen muodon: "He jättivät minut pulaan, minun on tehtävä se kokonaan yksin." Kun Senge tunnisti tämän "raivaan tieni puskutraktorilla" -mallin ("siinä mallini taas on") hän kykeni näkemään ongelman rakenteellisesti syntyneeksi ja ryhtyi miettimään, mitä voisi tehdä itse. Kun toimiva rakenne on tunnistettu, siitä itsestään tulee osa vallitsevaa todellisuutta.

Luovalla jännitteellä Senge tarkoittaa vision ja vallitsevan todellisuuden välistä kuilua. Aitoa visiota on Sengen mukaan mahdoton ymmärtää ilman tarkoitusta, joka yksilöllisellä tasolla merkitsee kysymystä: "Mikä on elämäni tarkoitus?" Visio on erityinen määränpää, pääteasema ja halutun tulevaisuuden kuva, tarkoitus puolestaan abstrakti. Visio on "kuun valloittamista" ja tarkoitus "ihmisen kyvykkyyden edistämistä maailmankaikkeuden tutkimisessa". Aidosti luovat ihmiset käyttävät vision ja vallitsevan todellisuuden välistä kuilua muutosenergian tuottamiseen henkilökohtaisessa hallinnassa. Sama periaate ilmenee joissakin organisaatioissa "aidon välittämisen" periaatteena. Kun ihmiset välittävät aidosti toisistaan, he ovat luonnostaan sitoutuneita, tekevät sitä mitä he todella haluavat sekä ovat täynnä energiaa ja innostusta. jokaiselle henkilökohtaisen kasvun polulle astuminen on kuitenkin viimekädessä yksilöllinen valintakysymys, ketään ei voida pakottaa kehittämään henkilökohtaista hallintaansa.

\section{Henkilökohtaisen hallinnan ja tiimioppimisen välimaastossa: Reflektio- ja kyselytaidot}

Senge (1990, 191-202) määrittelee reflektiotaidot ajatteluprosessien hidastamisena ${ }^{11}$ siten, että tulemme tietoisemmaksi mentaalisten malliemme muodostumisesta ja niiden vaikutuksesta tekoihimme ja toimintaamme. 
Reflektiotaidoissa on keskeistä abstraktiohyppyjen tunnistaminen. Abstraktiohypyt rajoittavat oppimista, koska inhimillisen ajattelun ja mielen liikkeet tapahtuvat kirjaimellisesti valon nopeudella, yleistyksiin hypätään niin nopeasti, että niiden testausta ei edes ajatella. Näin tapahtuu, koska rationaalinen ajattelu on taipuvainen korvaamaan yksityiskohtien monilukuisuuden yksinkertaisimmilla abstraktioilla, joihin rationaalisen ajattelun avulla tehdyt johtopäätökset perustuvat. Käsitteiden abstrahointitaito rajoittaa oppimista silloin, kun abstraktiossa erityisistä yleisiin käsitteisiin tapahtuvat hypyt jäävät tiedostamatta. ${ }^{12}$

Abstraktiohyppyjen tunnistamiseen sisältyy kaksi oppimiseen liittyvää piirrettä, joilla on kantavuutta Sengen ajattelussa laajemminkin. Oppiminen sisältää keskeneräisyyden vaalimisen ja luopumisen ${ }^{13}$ prosesseja, jotka työntyvät esiin seuraavissa abstraktiohyppyjen tunnistamiseen käytettävissä kysymyksissä: Millaiseksi oletan todellisuuden (toiminnan, ihmisten) luonteen? Mikä on yleistykseni taustalla oleva tietoaines? Olenko halukas myöntämään, että yleistys saattaa olla epätarkka tai harhaanjohtava? Erityisesti viimeisen kysymyksen asettaminen on tärkeä tehdä tietoisesti, koska kieltävä vastaus merkitsee oppimismahdollisuuksien sulkeutumista.

Toinen reflektio- ja kyselytaitoihin sisältyvä mentaalisten mallien hallinnan väline on ns. vasemman käden sarakkeen $^{14}$ paljastaminen. Yleistäen kyse on ajateltujen ja puhuttujen merkitysten välisten erojen tunnistamisesta ja tiedostamisesta. Vasemman käden sarake konkretisoituu erilaisissa konfliktitilanteissa, joita manipuloidaan salaamalla tilanteeseen olennaisesti sisältyvää ajattelua. Ongelmia näissä tilanteissa ei kyetä kohtaamaan avoimesti, vaan keskustelua käydään muodollisen kohteliaasti ns. asian ympärillä. Vasemman käden sarakkeen (piiloisen mutta tietoisen ajattelun) paljastaminen on oppimisen kannalta sikäli hyödyllistä, että sen avulla voidaan nähdä, kuinka oma päättely ja omat toimenpiteet vaikuttavat tilanteen lukkiutumiseen.

Kyselyn ja oman näkökulman puolustamisen tasapainottaminen on kolmas reflektio- ja kyselytaitojen osa-alue. Kun toimitaan pelkän oman näkökulman puolustamisen logiikalla, ihmisillä on taipumus käyttää tietoainesta valikoivasti päämääränään väittelyn voittaminen. Kun kysely ja oman näkökulman puolustaminen yhdistetään, ei päämääränä enää ole väittelyn voittaminen, vaan parhaan mahdollisen perustelun löytäminen. Kun keskustelutilanteissa ovat sekä kysely että oman näkökulman puolustaminen läsnä, esitämme avoimesti omaa näkökulmaamme vahvistavan ja horjuttavan tietoaineksen, olemme aidosti kiinnostuneita näkemyksiimme sisältyvistä virheistä ja puutteista. jokainen täsmentää ajattelunsa ja esittää omat oletuksensa tavalla, joka houkuttelee toisia kyseenalaistamaan niitä ja tuottamaan erilaisia näkemyksiä.

Julki- ja käyttöteorioiden välisen eron kohtaaminen toimii reflektio- ja kyselytaitojen käytännöksi siirtymisen kriteerinä. Julkiteorioiden (se niitä sanotaan) tasolla oppiminen on uuden informaation vastaanottamista, uusien ideoiden syntyä sekä uusien käsitteiden omaksumista ja käyttöä. Käyttöteorian tasolla oppiminen ilmenee konkreettisena käyttäytymisen muutoksena.

\section{Tiimioppiminen: Dialogi ja keskustelu}

Tiimioppiminen (Senge 1990, 239-249; Isaacs 1994, 357-364) on henkilökohtaisen hallinnan taitoalueiden laajentamista ja laajentumista, reflektio- ja kyselytaidot ovat pitkälti identtisiä dialogissa ja keskustelussa tarvittaville taidoille. Tiimioppimisen ytimenä oleva dialogi perustuu fyysikko ja kvanttiteoreetikko David Bohmin näkemykseen, jonka mukaan ajattelu on perimmiltään kollektiivista. Esimerkiksi kieli, asenteet ja oletukset ovat näitä kulttuurisesti hyväksyttyjä kollektiivisia määreitä.

Oppivaan organisaatioon sisältyvä visiomaisuus ja tavoitetilaluonne painottuu dialogia koskevissa määrityksissä: "Dialogi on erityistä keskustelua, joka alkaa elää omaa elämäänsä ja kehittyy suuntiin, joita emme etukäteen olisi voineet kuvitella tai suunnitella." (Senge 1990, 239)

Molemmat tiimioppimisen perusdiskurssit, dialogi ja keskustelu ovat välttämättömiä, jotta tiimi kykenisi jatkuvaan generoivaan oppimiseen, mutta diskurssien voima on niiden synergiassa. Synergian syntymisen edellytyksenä on, että diskurssityyppien - eli dialogin ja keskustelun - välinen ero ymmärretään.

Sanalla "keskustelu" on sama juuri kuin sanoilla "isku" ja "tärähdys"15. Jos keskustelua verrataan peliin, se muistuttaa pöytätennistä, jossa palloa lyödään kahden pelaajan välillä edestakaisin. Pelin tarkoituksena on normaalisti voittaa ja tässä tapauksessa voittaminen merkitsee sitä, kuinka joku ryhmän jäsenistä saa toiset hyväksymään oman näkemyksensä. Ryhmän yksittäinen jäsen voi satunnaisesti hyväksyä osia toisten ryhmän jäsenten näkemyksistä vahvistaakseen omaa näkemystään, mutta haluaa perustaltaan säilyttää oman näkemyksensä. Kuitenkin jos asetetaan ensisijaiseksi tavoitteeksi yhtäpitävyys ja totuus, ei voittamista painottava keskustelu enää riitä, vaan tarvitaan dialogia.

Sanan dialogi juurena on kreikankielinen dialogos. Dia merkitsee jonkin läpi, jonkin kautta. Logos merkitsee suppeammin sanaa ja laajemmin merkitystä. Dialogi tarkoitti alkuperäisessä muodossaan merkitystä, joka 
kulkee jonkun ohi tai läpi, vapaata merkitysten virtaa ihmisten välillä samassa mielessä kuin vesi virtaa kahden joentörmän välissä. Dialogissa ryhmä hyväksyy "yhteisten merkitysten altaassa olemisen tilan", jota ei hyväksytä yksilöllisesti. Tässä tilassa kokonaisuus organisoi osia pikemminkin kuin osia muovattaisiin kokonaisuudelle soveltuviksi. ${ }^{16}$

Dialogissa ryhmä tekee tutkimusmatkoja monimutkaisiin ja vaikeisiin kysymyksiin käyttäen monia erilaisia näkökulmia. Yksilöt jättävät esittämänsä oletukset avoimiksi ${ }^{17}$ kommunikoiden ne kuitenkin vapaasti. Tuloksena on vapaa asioiden tutkiminen, mikä nostaa ihmisten kokemukset ja ajattelun koko laajuudessaan dialogiin. Dialogi auttaa näkemään ajattelumme esityksellisen ja osallistuvan luonteen. Se muuttaa ajatteluamme vastaanottavaisemmaksi ja varmistaa, että olemme tietoisia ajattelumme epäyhtenäisyydestä. Dialogissa yksilöistä tulee oman ajattelunsa havainnoitsijoita.

Osallistujat alkavat ymmärtää jatkuvana prosessina käynnissä olevan "ajattelun" ja tämän prosessin tuloksena syntyvän "ajatuksen" välisen eron. Tämän eron ymmärtäminen on erittäin tärkeä pyrkiessämme ajattelumme yhtenäistämiseen. jos kollektiivinen ajattelu on joen jatkuva virta, ovat ajatukset kaarnan palasia, jotka ajelehtivat veden pinnalla ja huuhtoutuvat joen rantamille. Keräämme löytämämme kaarnan palaset talteen. Pidämme näitä kaarnan palasia, ajatuksia, ominamme, koska emme kykene näkemään ajatusten kollektiivista virtaa, josta palaset on poimittu. Dialogissa osallistujat alkavat nähdä joen virtauksen rantatörmien välissä, he uskaltautuvat yhteisten merkitysten altaaseen, joka tekee heidät kykeneviksi jatkuvaan kehittymiseen ja muutokseen. Normaalit ajatusprosessimme ovat kuin harvasilmäisiä verkkoja, jotka keräävät joen virrasta vain suurikokoisia elementtejä. Dialogissa kehittyy sensitiivisyyttä, joka on verrattavissa tiheäsilmäiseen verkkoon ja joka kykenee keräämään ajatusten virrasta hienovaraiset ja -jakoiset elementit.

Dialogi voi syntyä vain, jos ryhmä ihmisiä suhtautuu toinen toisiinsa kolleegoina, keskinäistä halukkuutta, syvällistä näkemystä ja selkeyttä noudattaen. Suhtautuminen toisiin kolleegoina on ratkaisevaa myönteisen sävyn synnyttämisessä dialogiin ja vastapainona dialogin haavoittuvuudelle. ${ }^{18}$ Halukkuus pitää toista kolleegana on välttämätön dialogia käynnistettäessä. Kun pidämme toisiamme kolleegoina, tunnustamme oletusten avoimeen esittämiseen liittyvän riskin ja luomme tarvittavan turvallisuuden tunteen riskin kohtaamiseen.

Dialogin ylläpitäjän perustehtävänä on toimia prosessin edistäjänä ja pitää dialogi liikkeessä. jos joku osallistujista toimii tavalla, joka ei enää vastaa dialogin vaatimuksia, on tämä tilanne tunnistettava ja käytävä läpi dialogille asetetut ehdot. Dialogin ylläpitäjä joutuu aina tasapainoilemaan kahden herkän linjan välillä. Yhtäällä hänen on oltava tiedollisesti pätevä ja kykenevä auttamaan jokaisessa dialogin vaiheessa. Toisaalta hän ei voi ottaa "erityisasiantuntijan" tai "tohtorin" manttelia, joka vetäisi tiimin jäsenten huomion hänen ajatuksiinsa, mitätöisi heidän ideoitaan ja siirtäisi vastuuta tiimiltä dialogin ylläpitäjälle.

Jollei dialogissa ole mukana taitavaa ylläpitäjää, on ajattelutavoillamme taipumus siirtää tilanne dialogista kohti keskustelua. Tämä pätee erityisesti dialogin varhaisissa kehittämisvaiheissa. Kuitenkin taitava dialogin ylläpitäjä vaikuttaa prosessin kulkuun. Kun joku esittää tietyn havainnon, voi dialogin ylläpitäjä todeta esimerkiksi: "Myös vastakkainen mahdollisuus voi olla tosi." Tämänkaltaisilla dialogin ehtoja koskevilla huomautuksilla dialogin ylläpitäjän osallistuminen edesauttaa dialogin onnistumista. Taito käydä dialogia perustuu merkitysten virran kokemiseen ja sen nimenomaisen asian löytämiseen tästä merkitysten virrasta, mikä on sanottava juuri kyseisessä tilanteessa. Taitava dialogin ylläpitäjä sanoo vain sen, mitä tarvitaan kussakin tilanteessa. Hän ei sorru laajoihin abstrakteihin selityksiin, dialogi noudattaa niukkuuden periaatetta.

Kun tiimien kokemus ja taito kehittyy, dialogin ylläpitäjän merkitys vähenee ja hänestä tulee asteittain osallistuja muiden osallistujien tapaan. Dialogi syntyy "johtamattomana". Yhteisöissä, kuten esimerkiksi Amerikan intiaaneilla, joissa dialogi on ollut jatkuva käytäntö, ei dialogin ylläpitäjää ole käytetty.

\section{KIRJALLISUUS}

Giddens Antbony 1979. The Central Problems in Social Theory. The Macmillan Press. London.

Goodman Michael, Kemeny Jennifer and Roberts Charlotte 1994. The Language of Systems Thinking: "Links" and "Loops". Teoksessa Senge Peter Roberts Charlotte, Ross Richard, Smith Bryan and Kleiner Art (1994) The Fifth Discipline Fieldbook. Nicholas Brealy Publisbing Ltd. London.

Goodman Michael \& Karash Rick 1994. Widening and deepening. Teoksessa Senge Peter ym. (1994) The Fifth Discipline Fieldbook. Nicholas Brealy Publisbing Ltd, London.

Isaacs William 1994. Dialogue. Teoksessa Serge Peter ym. (1994) The Fifth Discipline Fieldbook. Nicholas Brealy Publishing Ltd. London.

Parsons Talcott 1951. The Social System. Routleage \& Kegan. London. 
Putnam Robert 1994. Risks and opportunities with "the left hand column". Teoksessa Senge Peter ym. (1994) The Fifth Discipline Fieldbook. Nicbolas Brealy Publishing Ltd. London.

Senge Peter 1990. The Fifth Discipline. Doubleday. London.

Senge Peter 1994. Moving Forward. Teoksessa Senge Peter ym. (1994) The Fifth Discipline Fieldbook. Nicholas Brealy Publishing Ltd. London.

Schön Donald 1983. The Reflective Practitioner. How Professionals Think in Action. Basic Books. New York.

Turner Barry 1992. The Symbolic Understanding of Organizations. Teoksessa Reed Michael \& Hugbes Micbael (ed) (1992)Rethinking Organization. Sage Publications. London.

\section{VIITTEET}

1 Senge käyttää käsitteitä väljästi, osin monimerkityksellisesti ja viittauksenomaisesti ideoitaan ja ajatuksiaan demonstroiden. Tässä artikkelissa en esitä Sengen systemaattista käsitekritiikkiä, vaikka pidän sitä tarpeellisena.

2 Postmodernissa organisaatioajattelussa arkkityypit on nähty jungilaiseen ajatteluun liittyvinä ylihistoriallisina ja kulttuurit ylittävinä määreinä (Turner 1992, 48-49). Senge (1994, 121) viittaa oman ja käytännönläheisemmän arkkityypin käsitteensä osalta järjestelmäajattelussa 1960-luvulta lähtien tapahtuneeseen kehitykseen, jossa järjestelmädynamiikan myötä ryhdyttiin käyttämään monimutkaisia kausaalisilmukoiden kuvauksia.

3 Senge (1990, 52) erottaa myös responsiivisen tason, joka on aikahorisontiltaan reaktiivista laajempi mutta todellisuustilatta generatiivista suppeampi.

4 "Oppimalla luomme uudestaan itseämme ja tulemme kykeneviksi tekemään jotain sellaista, jota emme koskaan ole kyenneet tekemään, kykenemme ottamaan uudelleen vastaan todellisuuden ja koko suhteemme siihen sekä laajennamme kykyämme olla elämänprosessin luova ja tuottava osa." (Senge 1990, 14)

5 Senge (1990, 271-272) itse arvioi oppivien organisaatioiden kehityksen olevan jossakin keksimisen ja innovaatioiden välimaastossa. Samoin kuin monet "oppivimmista" lentokoneiden prototyypeistä syöksyivät maahan, samoin monet oppivien organisaatioiden prototyypit tulevat epäonnistumaan kivuliain seurauksin. Kuitenkin juuri näistä kokeiluista opitaan eniten.

6 "Kirjani tarkoituksena ei ole vakuuttaa lukijoita siitä, että heidän tulisi valita oppivien organisaatioiden rakentamisen tie. Olen pikemminkin yrittänyt muodostaa kuvan millainen kyseinen organisaatio voisi olla ja kuinka sen rakentamisessa voidaan edetä, jotta lukijat voisivat arvioida millaisesta valinnasta on kyse. Tämä, niin kuin jokainen muukin valinta, on jokaisen tehtävä itse." (Senge 1990, 360)

7 Käsitteellisenä kulmakivenä järjestelmäajattelussa Senge käyttää käsitettä rakenne. Kuitenkin Yhdysvaltalaisen Sengen käyttämä 'rakenteen' käsite muistuttaa enemmän Giddensin (1979) rakenteistumisen käsitettä kuin vaikkapa Parsonsin (1951) rakenteen käsitettä, koska se sisältää prosessin, jossa toimivat subjektit aktiivisesti luovat ja myös halutessaan muuttavat niitä rakenteita, joiden "vankeja" he ovat.

8. Senge käyttää termiä 'detail complexity', jonka vastakohtana järjestelmäajattelussa on dynaaminen monimutkaisuus. Dynaamisessa monimutkaisuudessa syy ja seuraus on vain hienon hienosti erotettavissa ja siinä interventioiden vaikutukset eivät ole ilmiselviä. Dynaamista monimutkaisuutta luonnehtii edelleen se, että samalla toimenpiteellä voi olla lyhyellä ja pitkällä aikavälillä erilaisia vaikutuksia ja seuraukset ovat paikallisesti erilaisia. Tavanomainen ennustaminen, suunnittelu ja niihin liittyvät analysointivälineet eivät kykene käsittelemään dynaamista monimutkaisuutta. Esimerkkinä Senge mainitsee simulaatiot, joita tehdään jopa tuhansilla yksittäisillä muuttujilla ja niiden kaikilla mahdollisilla yksittäisillä riippuvuussuhteilla ja jotka voivat ehkäistä täysin olennaisten suhteiden ja tärkeiden keskinäisriippuvuuksien näkemisen.

9 Senge (1990, 58-63) esittää myös, että kaikilla järjestelmillä ekosysteemeistä organisaatioihin on optimaalinen kasvuvauhti, joka on aina huomattavasti hitaampi kuin nopein mahdollinen kasvuvauhti.

10 Sengen mukaan opimme parhaiten välittömän kokemuksen kautta. Oppimista rajoittaa kuitenkin se, että välitöntä kokemusta on vain harvoin mahdollista saada tärkeiden päätöksien seurauksista. Perinteisen työkulttuurin, tilannesidonnaisen toimintatavan ja pitkälle viedyn funktionaalisen työn organisoinnin ohella tätä edesauttaa se, että "syy" ja "seuraus" (eli vaikutusten vastavuoroiset virtaukset) sijaitsevat ajallisesti ja paikallisesti etäällä monimutkaisissa järjestelmissä.

11 Senge ei tematisoi eikä kokoa ajankäyttöä koskevia määrityksiään, vaikka ajankäytön problematisointi läpäisee hänen tarkastelunsa. Reflektiotaitojen osalta Senge nojaa Schönin (1983) ajatteluun.

12 Senge $(1990,193)$ esittää seuraavan esimerkin abstraktiohypystä, jossa pohditaan väitteen "Laura ei välitä ihmisistä" pätevyyttä. Laura on kolleegasi ja hänellä on joitakin tapoja, joita kanssaihmiset eivät ole tunnistaneet. Laura jakaa harvoin kiitosta kanssaihmisilleen, hän keskeyttää joskus toisten puheen ja tuijottaa usein hajamielisesti muualle kun 
toiset puhuvat hänelle. Näistä käyttäytymispiirteistä Luuran kolleegat tekevät johtopäätöksen, että Laura ei juurikaan välitä ihmisistä. Tämä on yleisesti tiedossa lukuun ottamatta Lauraa, joka tuntee itse välittävänsä ihmisistä erittäin paljon. Lauran kolleegat ovat tehneet abstraktiohypyn, he ovat korvanneet useat erilaiset käyttäytymispiirteet yleistyksellä "Laura ei välitä ihmisistä". Mikä vielä tärkeämpää, Lauran kolleegat alkavat pitää yleistystä tosiasiana.

13 Senge ei käytä mainittuja käsitteitä, tulkinta on artikkelin tekijän.

14 Sengen tarkastelu nojaa tältä osin Chris Argyrikseen, jonka toimintateoreettinen tutkimus on muutoinkin keskeinen Sengen oppivissa organisaatioissa.

15 Englanniksi discussion, percussion ja concussion.

16 Dialogin tarkoitus on päästä kaikkien yksilöiden ymmärryksen taustalle, rajojen taakse. Syntyy uudentyyppinen ymmärrys, joka perustuu yleisen merkityksen kehittymiseen. Ihmiset eivät ole enää ensisijaisesti oppositiossa toisiinsa, eivätkä myöskään vuorovaikutussuhteessa toisiinsa. Pikemminkin he uiskentelevat yhteisten merkitysten altaassa, mikä tekee heistä kykeneviä pysyvään kehitykseen ja muutokseen.

17 Oletusten avoin esittäminen merkitsee niiden pitämistä esillä jatkuvalle kyselylle ja havainnoinnille. Tämä ei merkitse oletusten hylkäämistä, tukahduttamista tai pidättäytymistä oletusten tai subjektiivisten mielipiteiden ilmaisemisesta. Tämä merkitsee, että olemme tietoisia oletuksistamme ja pidämme niitä esillä tutkiskelua ja arviointia varten. Tätä ei voida tehdä, jos puolustamme mielipiteitämme tai jos emme ole tietoisia oletuksistamme ja niistä näkemyksistä, joihin oletuksemme perustuvat. Tilanteessa jossa yksilö "kaivautuu. kuoppaansa" ja päättää että "asiat ovat juuri näin", dialogi sulkeutuu.

18 Dialogiin (samoin kuin vasemman käden sarakkeen käyttöön reflektio- ja kyselytaidoissa) saattaa sisältyä "terapeuttisia" riskejä, joita ei tässä yhteydessä ole analysoitu tarkemmin. "Huolestumine, jos joudumme pitämään oletuksemme avoimena julkisesti. Saatamme jopa olla epävarmoja onko psykologisesti turvallista esittää avoimesti kaikki oletukset. "Eikö minun olisi viisasta jättää ainakin osa oletuksistani esittämättä, jotta en menettäisi identiteetin tunnettani?" (Senge 1990, 246; Putnain 1994, 250252) 